\title{
Misterio y Figura de Cide Hamete Benengeli
}

\author{
EDGARDO RIVERA MARTÍNEZ \\ Universidad Nacional Mayor de San Marcos \\ $\&$
}

Resumen

Este breve artículo trabaja scbre esa figura festiva, paróoica, pero también sugerente y enignática, de Cide Hamete Benengeli, coautor, por así decir, de la historia del ingenioso hidalgo. Este trabajo no se detiene en el marco de la dora cervantina, dirige también la atención a sus avatares o reencamaciones, pues ellos dan testimonio, por encima de sus explícitas características, de la viviente riqueza de posibilidades contenidas en el personaje que nos legó Miguel de Cervantes Saavedra.

Palabras claves: Don Quijote de la Mancha, Cide Hamete Benengeli, Miguel de Cervantes.

\section{Abstract}

This article focuses on Cide Hamete Benengeli, festive and suggestive character introduced to us by cervantes himself as a co-writer of his book. Also, by getting deep inside, this article presents succesive reincamations of Cide Hamete which offer testimany of the richness of passibilities brought forthby this fictional character.

Key words: Don Quijote de la Mancha, Cide Hamete Benengeli, Miguel de Cervantes.

\section{Introducción}

Ya en la frase con que empieza el Quijote se muestra una presencia

Y que no es exactamente la del autor ni la del narrador, sino la de lo que llamaríamos, sin ánimo de jugar con las palabras, un narradorautor. Pues aquel que habla de un lugar del cual no quiere acordarse, es también el mismo que se divierte más adelante, capítulo a capítulo, con los breves textos que los encabezan y resumen; el mismo enunciante 
que se refiere a los «anales de la Mancha» y que señala discrepancias entre «los autores que de este caso escriben»; $Y$, sobre todo, aquel que remite a un Cide Hamete Benengeli, autor del texto, del cual la obra sería traducción, a la manera como pretendían algunos libros de caballería.

Todo ello ha inducido a algunos estudiosos y, en especial, al autor de las excelentes notas de la edición de la novela que ha publicado la Real Academia Española de la Lengua, Francisco Rico, a puntualizar que «ni esas ni otras referencias a las diversas fuentes y opiniones en torno a la historia de don Quijote se dejan conciliar en un sistema coherente; pero se trata de bromas y parodias diáfanas, que en ningún momento pretenden ni pueden confundir al lecton». (2004: LXXXVII) . No obstante, si vamos más allá de lo paródico supuestamente diáfano o de un inexistente sistema, o de divertidas confusiones o contradicciones, ¿no se prookuce, acaso, a contrapelo de la voluntad de Cervantes, y al margen de las convenciones que adopta, un fenómeno más complejo?, ¿no hay en la figura del cronista arábigo un cierto y poético misterio, que le da, por así decir, vida propia, y que conviene seguir incluso más allá de la obra cervantina?

\section{2. ㅌl autor Cide Hamete Benengeli en el Quijote}

Es en el capítulo IX de la primera parte, «Donde se concluye y da fin a la estupenda batalla que el gallardo vizcaíno y el valiente manchego tuvieron», donde se menciona por primera vez a ese narrador-traductor, entretejido a ratos con el primero, y de arábigo nombre, Cide Hamete Benengeli. Elllo sucede luego de que al final del capítulo anterior queda en suspenso la batalla entre el caballero andante y el vizcaíno: «en aquel punto tan dudoso paró y quedó destroncada tan sabrosa historia, sin que nos diese noticia su autor dónde se pooría hallar lo que della faltaba.» Y dice luego el texto: «Pero está el daño de toob esto que en este punto y término deja pendiente el autor desta historia esta batalla, disculpándose que no halló más escrito destas hazañas de don Quijote..Bien es verdad que el segundo autor desta obra no quiso creer que tan curiosa historia estuviese entregada a las leyes del olvido.». 
Este «segundo autor» no perdió la esperanza, desde luego, y así fue cómo después de un tiempo, y por puro azar, estando un día en el Alcaná de Toledo, llegó un muchacho a vender unos cartapacios con papeles viejos. Tomó uno de ellos, y encontró que estaba escrito en arábigo, y como acertó a pasar por allí un morisco aljamiado, le rogó que los tradujese. Así lo hizo éste, y comenzó a leer y a reírse, pues se trataba de un pasaje relativo a Dulcinea. Leyó luego el título, que decía: «Historia de don Quijote de la Mancha, escrita por Cide Hamete Benengeli, historiador arábigo.» Contento en sumo grado, compró el narrador los papeles, y encargó al morisco que los vertiera al castellano, lo cual hizo este por «dos arrobas de pasas y dos fanegas de trigo, en poco más de mes y medio. Y así pudo saberse, pues, la continuación del duelo y de la historia toda.

Anotemos que allí no se dice sabio ni encantador, sino historiador, pero ¿cómo podía saber éste, punto por punto, los hechos y dichos del manchego y su escudero, y de los demás personajes, sino por arte de sabiduría o encantamiento, como el que asistía a los narradores supuestamente primeros de los hechos de Amadís o de Esplandián? En lo inmediato se trata sin duda de un intermediario colocado por Cervantes en graciosa o irónica parodia de los magos que oficiaban de cronistas en los libros de caballerías ${ }^{1}$, invención que le permite especiales efectos de comicidad, color y contraste, y que resulta, además, por curioso que parezca, creación del mismo don Quijote -sí, del ingenioso hidalgo- en la medida en que él da siempre por sentado que un sabio desconocido pondrá por escrito -o mejor aún pone por escrito-, puntual y simultáneamente, todas sus acciones. Así, tenemos a don Quijote inventor de su narrador y a su vez criatura de éste.

Recordemos cuán numerosos son los encomios y alabanzas que prodiga Cervantes a su alter ego. Citemos por ejemplo, en el capítulo XVI de la Primera Parte, las siguientes palabras: «Fuera de que Cide Mahamate Benengeli fue historiador muy curioso y my puntual en todas las cosas.» Pues bien, lo sorprendente es que esa primera parte omite una referencia explicita al arábigo al llegar a su conclusión, y dice en cambio:

Pero el autor desta historia, puesto que con arriosidad y diligencia ha buscado los hechos que don Quijote hizo en su tercera salida, no ha 
podidb hallar noticia de ellas, a lomenos, por escrituras auténticas; solo la fama ha uardado, en las memorias de la Mancha, que Don Quijote la tercera vez que salió de su casa fue a Zaragoza, donde se halló en unas famasas justas que en aquella ciudad hicieron, y allí le pasaron cosas dignas de su valor y buen entendiiento. Ni de su fin y acabamiento pudo alcanzar cosa alguna, ni la alcanzara ni supiera si la buena suerte no le deparara un antiguo médico que tenía en su poder una caja de plomo, que, según él dijo, había hallado en los cimientos derribados de una antigua ermita que se renovaba; en la cual caja se habían halladb algunos pergaminos escritos con letras góticas, pero en versos castellanos, que contenían muchas de sus hazañas y daban noticia de la hermosura de Dulcinea del Toboso, [...] Y los que aquí se pudieron leer y sacar en limpio fueon los que aquí pone el fidedigno autor desta nueva y jamás vista historia. El aral autor no pide a los que la leyeren, en premio del inmenso trabajo que le costó inquirir y buscar todos los archivos manchegos, por sacarla a luz, sino que le den el mesmo crédito que suelen dar los discretos a los libros de caballerías, que tan validbs andan por el mundo; que con esto se tendrá por bien pagadb y satisfecho, y se animará a sacar y buscar otras, si no tan verdaderas, a lo menos de tanta invención y pasatiempo.

¿Quién fue aquel médico, y cómo se topó con él Cide Hamete, y qué hizo este con esa caja de plomo? Nada se dice al respecto. Si ahora pasamos al final de la Segunda Parte, hallamos que acaba, volviéndose al tono del comienzo, a pesar del melancólico fallecimiento de Alonso Quijano. El prudentísimo Cide Hamete dijo a su pluma:

Aquí quedarás, colgada desta espetera y deste hilo de alambre, ni sé si bien cortada o mal tajada péñola mía, adonde vivirás luengos siglos, si presuntuosos y malandrines historiadores no te descuelgan para profanarte. Pero antes que a ti lleguen, les puedes advertir, y decirles en el mejor modo que pudieres:

\section{De ningumo sea tocada;}

Porque esta empresa, buen rey,

Para mí estaba guardada.

iTate, tate, folloncicos!

Para mí sola nacio Don Quijote, y yo para él; él supo dorar y yo escribir; solos los dos samos para en uno, a despecho y pesar del escritor fingido y tordesillesco que se atrevió, o se ha de atrever, con pluma de avestruz 
grosera y mal adeliñada las hazañas de mi valeraso caballero, porque no es carga de sus harbros, ni asunto de su resfriado ingenio [... . .

Y líneas más adelante:

Y con esto cumplirás con tu cristiana profesión, aconsejando bien a quien mal te quiere, y yo quedaré satisfecho y ufano de haber sido el primero que gozó el fruto de sus escritos enteramente, camo deseaba, pues no ha sido otro mi deseo que poner en aborrecimiento de los hombres las fingidas y diparatadas historias de los libros de caballerías, que por las de mi verdadero don Quijote van ya tropezando, y han de caer del todb, sin duda alguna. Vale.

De otro lado, si la primera parte de la novela se integra en el mundo de la segunda, es precisamente por arte de ese taumaturgo. Como dice el estudioso Edward Riley: «Benengeli viene a justificar todas las creencias de don Quijote, porque su existencia real demuestra que los encantadores de aquellos fantasiosos libros existen en realidad, y no sólo en la imaginación del hidalgo.»

Se dirá que muchas de las referencias a Cide Hamete oscilan entre el remedo humorístico y la nota situacional. Sin duda es así, pero no podrá negarse, además, que no deja de haber un halo que rodea a ese narrador sui generis. No en vano otro crítico, G. L. Stagg, ha sostenido que Cervantes pudo haber tenido en mente, como indicaría el título de Cide, a los morabitos de Argel, hombres santos versados en nigromancia, y por ello detentadores de un raro poder y sapiencia. Y de tal modo, diríamos, que el lúdico tratamiento de que Cervantes hace objeto a Benengeli se vuelve contra él, pues resulta ficcionalizado precisamente por ese poético alter ego, supuestamente conocedor de toobs los misterios.

\section{Cide Hamete Benengeli: Una vida propia}

Demos un paso ahora, como nos propusimos, más allá de la obra y época de Cervantes, en pos de los avatares de Cide Hamete. Encontramos así, más de dos siglos después, unas «Adiciones a la historia del ingenioso hidalgo don Quijote de la Mancha. Continuación 
de la vida de Sancho Panza», rarísimo librito que se publicó, sin nombre de autor (ignoro si su identidad ha sido ya revelada), allá en Madrid en 1845, obra que, por su prosa, por su manejo del humor y por el notable pastiche que su estilo constituye, bien merecería situarse en un nivel casi comparable a los «Capítulos que se le olvidaron a Cervantes» de Juan Montalvo. Pues bien, las «Adiciones» incluyen como apéndice unas «Memorias del esclarecido Cide Hamete Benengeli, recogidas por Melique Zulema, autor igualmente verdadero que arábigo.» ¿Por qué las escribió e incluyó el autor de la novelita? No lo sabemos. Sea como fuere, en sus páginas, que no son muchas para ser memorias, y que incluyen un grabado con la supuesta figura del biografiado, se cuenta que este nació en la patria de Averroes, en África, hijo de un sastre y una plañidera de difuntos y barrendera de mezquita. Aprendió el oficio de su padre, pero se inició también en otros menesteres. Fra buen músico, y en especial con el pandero de cascabel, «a cuyo son bailaba la zambra con mucho primons. Fue también, se nos dice, gran cocinero, como que preparaba el alcuzcuz y el azemite como nadie. Pero fue sobre todb aficionadb a los libros y a la escritura. Pues bien, la suerte quiso que cayese prisionero de un genovés que se lo llevó como esclavo a España, donde al cabo de unos años, supo en Aragón de don Quijote y dedicó parte de su tiempo a tomar minuciosa nota de sus hechos. Fue a dar luego al servicio nada menos que de los Duques en cuyo palacio se alojó al manchego, donde lo conoció personalmente, y sus señores «le dieron tiempo y proporción para que continuase la historia de don Quijote, con arreglo a sus apuntaciones, y otras que el mismo mayordomo [Tosilos] le dio [...] ». Más aún, como este nuevo Hamete era alegre y chancero, fue quien ideó la burla de la doncella Altisidora, la batalla gatuna en el jardín del palacio, y confeccionó con colgaduras viejas las prendas necesarias para los cómicos episodios con que se solazaron, a costa de nuestro caballero, sus nobles huéspedes.

Extraña, sin duda, la imagen que en las «Adiciones» ofrece el cronista arábigo, por su cercanía, a destiempo, con la picaresca, y alejada, por cierto, del encantador de misterioso poder que sugieren algunas de las referencias del Quijote. Y lo más llamativo aún, que Cide Hamete a su vez tuviese otro informadísimo cronista, Melique Zulema, autor 
igualmente arábigo. O, como quien dice, que Cide Hamete tuviese a su vez su propio Cide Hamete.

Pasemos ahora a otra continuación de la novela de Cervantes, de fines del siglo XIX, cual es la de «Capítulos que se le olvidaron a Cervantes», del ecuatoriano Juan Montalvo. En ella no se pretende, hasta donde recordamos, que la obra sea una traducción del árabe. Más aún, ya al final de ella, el capítulo LVIII se titula, marcándose una significativa distancia: «Capítulo de los menos parecidos a los de Cide Hamete Benengeli». Y en el postrero dice el encabezamiento: «Donde el historiador da fin a su atrevido empeño, no de hombrearse con el irmortal Cervantes, ni de imitarle siquiera, sino de suplir, con profundo respeto, lo que a él se le fue por alto». No, Juan Montalvo no quiso saber nada con el oriental cronista.

Décadas más tarde, Jorge Luis Borges no pudo dejar de referirse a un juego tan singular como el que, más allá de lo paródico, se da en la obra cervantina. Lo hace en un texto breve, Magias parciales del Quijote, incluido en Otras Inquisiciones, donde dice que Cervantes se complacía en confundir lo dojetivo y lo subjetivo, y que «la forma del quijote le hizo contraponer a un mundo imaginario poético, un mundo real prosaico. A las vastas y vagas geografías del Amadís opone los polvorientos caminos y los sórdidos mesones de Castilla». Y más adelante: «El plan de su obra le vedaba lo maravilloso; éste, sin embargo, tenía que figurar, siquiera de manera indirecta [...e] insinuó lo sobrenatural de un modo sutil, o, por ello mismo, más eficaz. Intimamente, Cervantes amaba lo sobrenatural». Se inicia de ese modo en el ya citado Capítulo IX de la Primera Parte un juego de lo que el autor argentino llama «extrañas ambigüedades», que culminan en la Segunda, donde los protagonistas han leído la Primera y son, al mismo tiempo, protagonistas de la historia del ingenioso hidalgo.

De otro lado Cide Hamete Benengeli le recuerda a Borges, al misterioso doctor Diógenes Teufelsotroeckh, protagonista de una novela de T. Carlyle, para el cual todas las instituciones, formas y símbolos son ropajes, nada más que ropajes, o, como quien dice, ilusiones.

Más aún y más adelante, don Quijote será, como constata Borges, y merced al historiador arábigo, lector del quijote, y el quijote tendrá como su lector privilegiado al propio don quijote, así como Hamlet es 
espectador de Hamlet. ¿Cómo puede ser eso? Borges responde: «Creo haber dado con la causa: tales inversiones sugieren que si los caracteres de una ficción pueden ser lectores o espectadores, nosotros, sus lectores o espectadores, podemos ser ficticios».

Si ahora pasamos a las letras de nuestra patria nos encontraremos con un cuento memorable de Luis Enrique Tord, «Cide Hamete Benengeli, coautor del Quijote», incluido en el libro de relatos «Espejo de Constelaciones» (1991) . Obra de ficción que nos brinda como protagonista a un Cide Hamete opuesto en todo al del libro madrileño de mediados del siglo XIX. Un personaje de origen morisco pero convertido, como su familia, al cristianismo, y que conoció en la cárcel de Sevilla a Cervantes, a quien habló de los hechos y espiritualidad de un Caballero del Desierto imbuido de religiosidad sufita, y que vino a dar al Perú e ingresó a la Orden Franciscana en Huamanga, donde tomó el nombre de fray Diego de la Santa Fe. Allí en el monasterio redactó un manuscrito confesional en 1627, en el cual da cuenta de sus orígenes y de su conversión, así como de su sonpresa al llegar a sus manos y leer la Primera Parte de la novela de Cervantes, con un Alonso Quijano en muchísimos aspectos calcado de aquel descrito por Hamete ben Gelie, (que tal era su nombre original), personaje de «alma noble asediada, agredida y burlada por las apariencias», «alegoría sufí del viaje del alma y del peligroso juego de apariencias que es la realidad». Un Cide Hamete, pues, con nada de festivo y paródico, sino próximo a los morabitos de que habla el estudioso G. L. Stagg. Y que además, por la difusión del hermoso cuento de Tord, y una extraña lectura del mismo, ha dado lugar a que algunos eruditos, según se ha dado a conocer por un asombrado periodista, Abelardo oquendo, hayan dado por sentado de que allá en Huamanga sí existen y no son inventados ciertos papeles que tienen que ver con el imaginado autor arábigo. Y tanto que a lo mejor hay ahora allá un empeñoso profesor enfrascado en saber de ese fray Diego de la Santa Fe.

Para terminar, pues, me permito señalar mi cercanía con el modo de pensar de Jorge Luis Borges, y manifestar que veo en la figura de Cide Hamete también un poético y vivo misterio, y tanto, que bien podríamos ser todos una nueva invención suya. 


\section{Nota}

1 El recurso de introducir un narrador ficticio es por cierto antiguo. Veamos algunos ejemplos en la narrativa de caballerías. Ya el presunto autor del Amadís de Gaula, señalaba que había «corregidos tres de los libros de la novela, y escrito (?) corregido el cuarto. Trabajo que extendió a las Sergas de Esplandián, supuestamente de mano del gran maestro El izabad, rescatadas en una aventura por Amadís, y halladas en una tumba de Constantinopla y traídas por un mercader húngaro. Cosa semejante había sucedido antes con El caballero Cifar, novela caballeresca supuestamente traducida del griego al latín, y del latín al español; y con Tirant lo Blanch (1490) , cuyo autor aduce que fue escrita en inglés y traducida luego al portugués, y de ésta versión al catalán. Un precedente más cercano es el Libro del invencible caballero Lepolema.el caballero de la Chuz (1521 - 1600), ayyo supuesto autor es el árabe Xarton, antecesor del cronista de las hazañas del caballero de la Triste Figura (Thamas 52 y 101) .

\section{Referencias bibliográficas}

BORGES, Jorge Luis (1968) : Otras inquisiciones. Emecé, Buenos Aires. CERVANTES, Miguel de (2004) [1605-1615] : Don Quijote de la Mancha. Real Academia Española, Asociación de Academias de la Lengua Española, San Pablo.

RICO, Francisco (2004) : «Notas al texto». En: Don Quijote de la Mancha. Real Academia Española, Asociación de Academias de la Lengua Española, San Pablo; pp. IXXVI-XCII.

RIEY, Eblward (1990): Introoucción al Quijote. Crítica, Barcelona. THONAS, Henry (1952) : Las novelas de caballería españolas y portuguesas. CSIC, Madrid.

TORD, Luis Enrique (1991) : Espejo de constelaciones. Editorial Antártica, Lima. 